\title{
IN NOVATION OF ZEOLITE MODIFIED POLYETHERSULFONE HOLLOW FIBRE MEMBRANE FOR HAEMODIALYSIS OF CREATININE
}

\author{
Bella Prelina ${ }^{1}$, Januardi Wardana ${ }^{1}$, Ahya Isyatir R. ${ }^{1}$, Zakiyatus Syukriyah ${ }^{1}$, Siti Wafiroh ${ }^{1}$, \\ Yanuardi Raharjo ${ }^{1}$, Murobbiyatul Wathoniyyah ${ }^{1}$, Alfa Akuista Widati ${ }^{1}$, Mochamad Zakki \\ Fahmi ${ }^{1, *}$
}

https://doi.org/10.23939/chcht12.03.331

\begin{abstract}
Zeolites were added to polyethersulphone (PES) membranes in order to enhance their capability of attracting creatinine. Zeolite was blended with PES by varying its doping concentration and time, and the mechanical properties of the resulting hollow fibre membranes produced under optimal concentration were characterised. The values of tensile stress, tensile strain and Young's modulus, as well as the flux and rejection of the membranes were determined.
\end{abstract}

Keywords: zeolite, hollow fibre, creatinine, haemodialysis.

\section{Introduction}

In recent years the Indonesian health ministry has reported an increasing national trend in annual catastrophic incidents due to diseases. A catastrophic disease by nature incurs high therapeutic costs and often leads to complications that can endanger the lives of sufferers, and includes afflictions such as the kidney, heart, and neurological disease, cancer, diabetes mellitus, and haemophilia. The number of patients with chronic kidney disease in Indonesia continues to grow, mostly due to complications from hypertension and diabetes mellitus. According to the data released from the Indonesian Nephrology Association (PERNEFRI), over 28,000 patients in Indonesia suffer from renal failure, with the number increasing $10 \%$ annually [1].

In the last decade, haemodialysis (HD) has been developed as a kidney replacement therapy that can increase a patient life expectancy, and is currently being improved continuously in many countries. Haemodialysis

\footnotetext{
${ }^{1}$ Faculty of Science and Technology, Universitas Airlangga, Mulyorejo-Surabaya 60115, Indonesia

*m.zakki.fahmi@fst.unair.ac.id

(C) Prelina B., Wardana J., Isyatir R.A., Syukriyah Z., Wafiroh S.,

Raharjo Y., Wathoniyyah M., Widati A., Fahmi M., 2018
}

requires a dialysis machine and a special filter called dialyser, which is a semipermeable membrane, to clean blood. In haemodialysis, blood is removed from a patient's body, filtered through the membranes, and drained into a machine located outside the body. Kidney failure is caused by the excess creatinine in blood; the normal concentration of creatinine in blood is $0.7-1.4 \mathrm{mg} / \mathrm{dl}$ [2]. The dialysis membranes used in HD require robust mechanical properties, must be highly efficient, and be capable of supporting significant flux. In a previous study [3], a cellulose acetate polymer was used to improve the performance of HD membrane, where the polymer performs a creatinine HD flux of $49.41 / \mathrm{m}^{2}$ and a rejection value of $\sim 19.65 \%$. This showed that the membrane allowed creatinine to pass through the dialyser. However, the disadvantage of the membrane used was its relatively low mechanical strength, and in particular, its brittleness. Thus, minimizing the poor performance of HD membranes has become an important issue that has not been clearly resolved.

Zeolites are widely used as dehydrators, adsorbents, molecular filters, and ion exchangers due to their unique properties. Their use as multipurpose materials in adsorbents and molecular filters is made possible in part by their hollow structures, which allow large numbers of molecules which diameters are smaller or equal to the membrane pore size to be absorbed. In addition, zeolites are selective adsorbents with high adsorption effectiveness. Zeolite is an attractive adsorbent due to its crystalline pores that have the diameter $\sim 0.85 \mathrm{~nm}$, making them a type of toxic uremic compound [4]. To investigate the use of zeolite in HD, several zeolites were added to poly(ethylene-co-vinyl alcohol) in order to separate creatinine, demonstrating an excellent creatinine rejection value of $67 \%$ [5]. Other polymers such as polyacrylonitrile and poly(methyl methacrylate) have also been used with zeolite in HD-related studies [6, 
7]. Moreover, an additional innovation has been the manufacture of hollow-fibre, polymer-based membranes such as polyethersulphone (PES). Polyethersulfone was chosen due to its improved resistance to fouling compared to natural and other synthetic polymer membranes, as well as their other excellent properties such as thermal stability, chemical resistance, and various mechanical properties $[8$, 9]. This research focuses on the use of hollow fibre membranes fabricated from zeolite-modified PES.

In principle, the modification of PES membranes with zeolite may enhance its selective molecular separation, but to date this technique has not yet been reported. Here, we report on the modification of PES membranes by zeolites, as used in creatinine HD for renal failure patients. In addition to characteristics of the zeolites, PES, and blended membrane, the performance of membranes in filtering creatinine was investigated and identified as a key aspect in need of improvement. The obtained membranes are expected to selectively filter creatinine during HD with high values of flux and rejection, while retaining excellent mechanical properties.

\section{Experiments}

\subsection{M aterials}

Polyethersulfone, sodium hydroxide $(\mathrm{NaOH}$, $98.5 \%$ ), creatinine $(98 \%)$, picric acid solution $(1.3 \%)$, sodium aluminate anhydrous $\left(\mathrm{NaAlO}_{2}, 50 \%\right)$, silicon dioxide $\left(\mathrm{SiO}_{2}\right)$ were purchased from Sigma Aldrich Pte Ltd (USA). Dimethyl formamide (DMF, $99.8 \%$ ) was purchased from Merck \&Co. Ltd (Canada). All reagents and solvents were used directly without further purification.

\subsection{Synthesis of Zeolite A}

Zeolite powder was prepared using hydrothermal methods. About $8.2 \mathrm{~g}$ of $\mathrm{NaAlO}_{2}$ was dissolved in $11 \mathrm{ml}$ of distilled water, then dropwise mixed with $5.2 \mathrm{ml}$ of $\mathrm{SiO}_{2}$ for aging step following by stirring process for $3 \mathrm{~h}$. The mixture was transferred on Teflon lined autoclave and heated in a convection oven at $373 \mathrm{~K}$ for $44 \mathrm{~h}$. The mixture was filtered to obtain a residue. This residue was further washed with distilled water, dried and calcined at $723 \mathrm{~K}$ for $4 \mathrm{~h}$.

\subsection{Fabrication of Polyethersulfone $\mathrm{H}$ ol- low Fibre Membrane M odified by Zeolite}

Spinning dope solution to fabricate zeolite modified polyethersulfone hollow fibre membranes was prepared with a fixed PES concentration and variation on both DMF and zeolite amount (see Table 1). PES was firstly dissolved in DMF under vigorous stirring at ambient temperature. Zeolite was further added to the homogenous solution and mixed until the zeolite was homogenously dispersed. The prepared dope solution was then set into spinneret hollow fibre system. Then the solvent (water) and dope were extruded through the inner and outer channel, respectively, of the spinneret at a controlled rate and passed through an air gap before immersing into a coagulation bath.

\subsection{Flux and Rejection of Creatinine Analysis}

Performance of the membrane on a haemodialysis process was accessed by measuring its flux and rejection of prepared creatinine solution. Flux is the volume of permeate that passes through the membrane per unit area and time. The flux values were determined by passing $100 \mathrm{ml}$ of feed solution into a cross-flow system, then the value was measured every $60 \mathrm{~min}$. The feed and permeate solutions of creatinine were separated by the crosslinked PES-zeolite hollow fibre membranes. The selectivity of membranes was determined by the rejection value. The rejection value of membranes was obtained by determining the concentration of the feed solution (solution before filtration process) and the permeate solution (solution after filtration process). The concentration of each solution was measured quantitatively using the UV-Vis spectrophotometer. The flux and rejection values of membranes were determined using Eq. (1) and (2), respectively:

$$
J_{v}=\frac{V}{A \cdot t}
$$

where $J_{v}$ is volume flux, $1 / \mathrm{m}^{2} \cdot \mathrm{h} ; t$ is time, $\mathrm{h} ; A$ is a membrane surface area, $\mathrm{m}^{2} ; V$ is a permeate volume, 1 .

$$
R=1-\frac{C_{\text {permeate }}}{C_{\text {feed }}} \cdot 100
$$

where $R$ is rejection, $\%$; $C_{\text {permeate }}$ is concentration of particles in permeate, mol \%; $C_{\text {feed }}$ is concentration of particles in the feed, mol \%.

\subsection{Characterization}

Stress-strain data were provided by Shimadzu Autograph AGS-X at $100 \mathrm{kN}$, where the hollow fibre membranes were cut with a length of $10 \mathrm{~cm}$. Then the membranes were clamped at both ends and pulled until they were broken. In the tensile test, three times replications were performed to obtain the data of force $(F)$ and length $(\Delta l)$ of the membranes. Spectrophotometer 
UV-Visible Mapada UV-6100PCS was used to determine the concentration of creatinine. The morphology of prepared membrane was provided by scanning electron microscopy (SEM) using Carl Zeiss EVO MA10. Goniometer and cross-flow system instruments were used to characterize the obtained hollow fibre membranes.

\section{Results and Discussion}

\subsection{Fabrication of Zeolite-M odified PES Hollow Fibre Membranes}

Initially, PES was dissolved in a DMF solvent at room temperature, and zeolite powder was then added to the solution and magnetically stirred until it became homogeneous. This mixture of PES, DMF, and zeolite is called a dope solution. Subsequently, phase inversion was used to cast the solution into hollow fibre membranes. An optimal membrane was produced by varying the zeolite composition added to the dope solution. Various dope solution compositions are shown in Table 1.

The optimal composition (wt \%) of the PES-zeolite hollow fibre membranes produced was: PES 17, DMF 82.5 and zeolite 0.5 ; this composition was used in the following analysis.

\subsection{Characterization of Zeolite and Zeolite-Modified PES Hollow Fibre Membrane}

$\mathrm{X}$-ray diffraction (XRD) was used to characterise the zeolite-modified hollow-fibre membranes. From the diffractogram shown in Fig. 1, the prepared zeolite displays a pattern of peaks confirming that a hydroxysodalite-type zeolite (JCPDS 31-1270) was produced, along with a small amount of zeolite V (JCPDS 39-0191) [10, 11]. The formation of multiple types of zeolites during synthesis was possible due to the complex formation mechanism used. The incorporation of zeolite into PES was investigated by Fourier transform infrared spectroscopy (FTIR). A comparison of the vibration spectra of PES-zeolite and bare PES is shown in Fig. 2. The vibration peaks of PES are the most evident in PESzeolite: the peaks at 1690, 1480, 1340 and $990 \mathrm{~cm}^{-1}$ indicate the stretching vibrations of $\mathrm{C}=\mathrm{C}, \mathrm{C}-\mathrm{H}, \mathrm{S}=\mathrm{O}$, and $\mathrm{C}-\mathrm{O}-\mathrm{C}$ in PES, respectively. The existence of zeolite in PES is indicated by the particular peak at $3600 \mathrm{~cm}^{-1}$, which is the $\mathrm{OH}$ vibration corresponding to a hydroxysodalite-type zeolite. Similarly, the shoulder peak at $1020 \mathrm{~cm}^{-1}$ and the strong peak at $750 \mathrm{~cm}^{-1}$ confirm the $\mathrm{Si}-\mathrm{O}-\mathrm{Si}$ and $\mathrm{Al}-\mathrm{O}$ vibrations of zeolite, respectively. Thus, zeolite was confirmed to be successfully incorporated into PES membrane.

Table 1

Optimization results of dope solution composition

\begin{tabular}{|c|c|c|l|}
\hline \multicolumn{2}{|c|}{ Composition, wt \% } & \multirow{2}{*}{ Performance } \\
\hline PES & DMF & Zeolite & \\
\hline 17 & 82.7 & 0.3 & Dope solution was casted easily to form a hollow fibre, but the resulted membrane was brittle \\
\hline 17 & 82.5 & 0.5 & Shape of hollow fibre membranes was well-ordered with a smoother surface \\
\hline 17 & 82.3 & 0.7 & The resulted membrane was thick and the surface was slightly rough \\
\hline 17 & 82.1 & 0.9 & Dope solution was difficult to cast into hollow fibre and the resulted membrane was rough \\
\hline
\end{tabular}

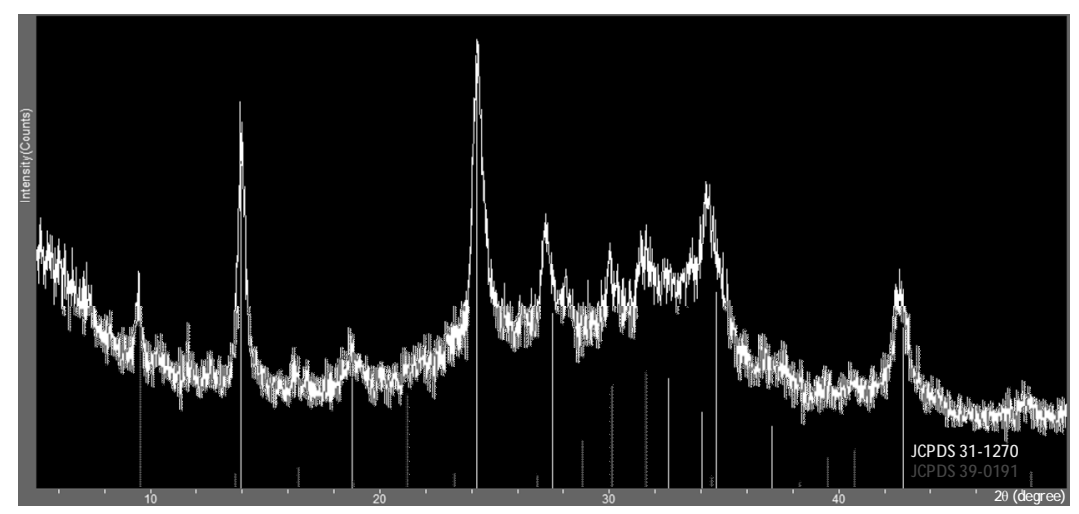

Fig. 1. Diffractogram of the synthesized zeolite type A 


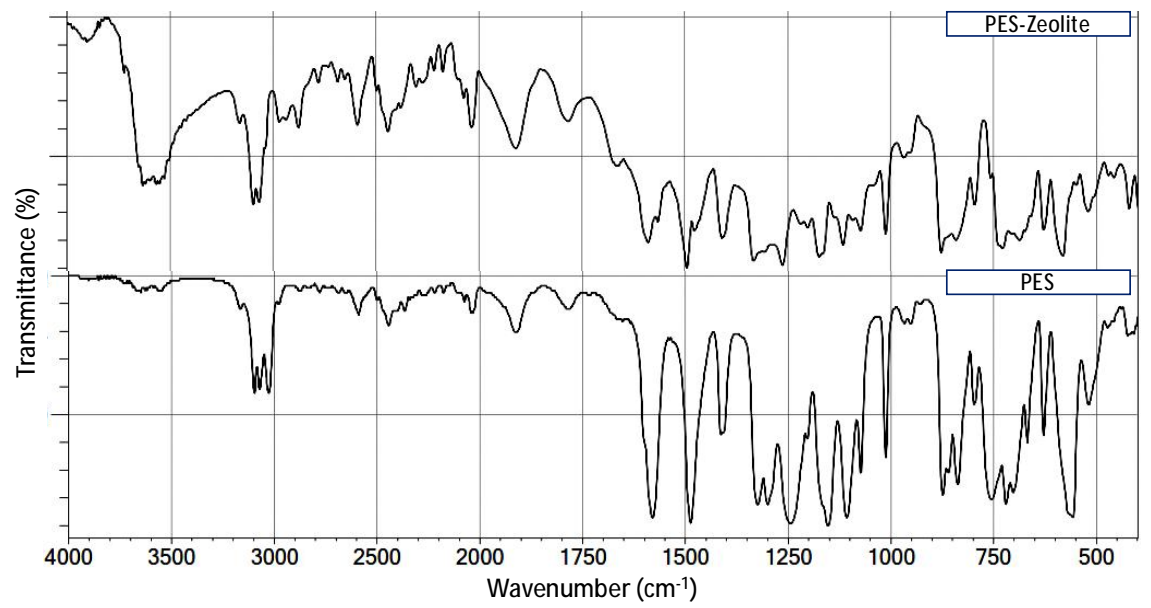

Fig. 2. FTIR spectra of PES-zeolite and PES
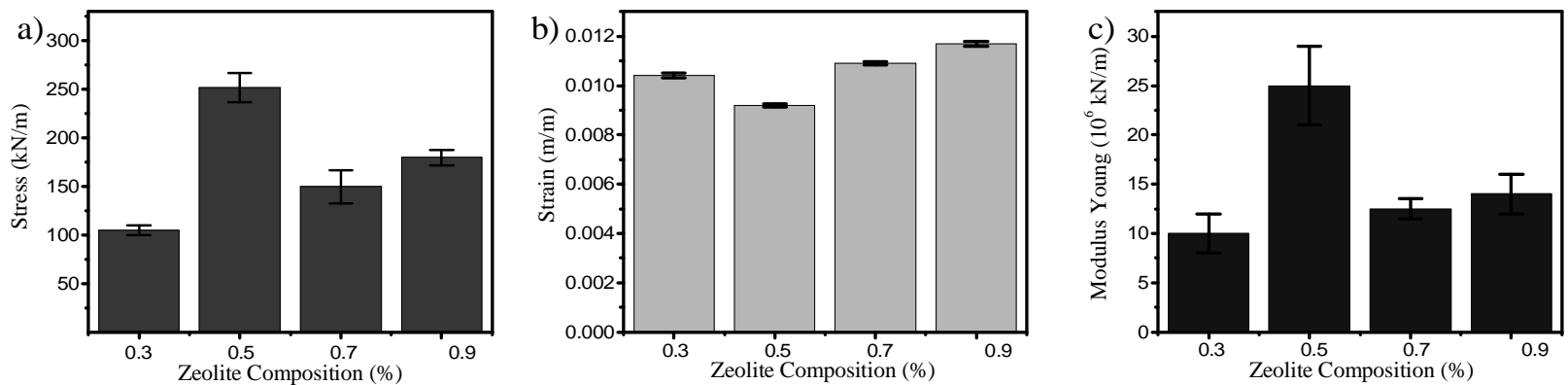

Fig. 3. Mechanical properties data of stress (a), strain (b), and Young's modulus (c) values.

The data were taken with multi replication $(n=3)$

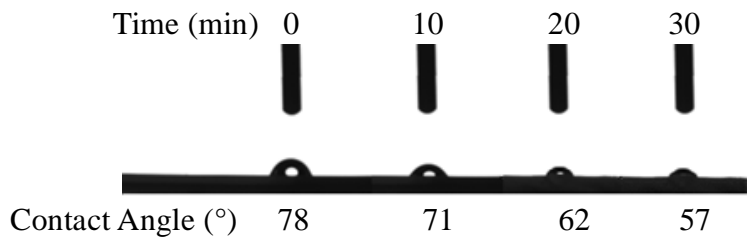

Fig. 4. Contact angels of dropped water on PEZ zeolite membrane

The mechanical properties of hollow fibre membranes were tested using an autograph instrument. By preparing specific specimen of the hollow fibre membrane, the stress, strain, and Young's modulus were measured and represented in Fig. 3.

Fig. 3 clearly shows that the stress in a PES-zeolite membrane with $0.5 \%$ zeolite can reach up to $\sim 250 \mathrm{kN} / \mathrm{m}$,; this indicates a tight structure resistant to damage. The strain value indicates the plasticity and elasticity of the material. The strain data show results opposite to the stress data. PES-zeolite membrane with $0.5 \%$ zeolite withstands the smallest strain. A lower strain value indicates that the membrane is more plastic. The stress and strain both affect Young's modulus, which can be used to characterise the structure, composition and defects of the membrane. Since membranes with high values of Young's modulus are needed for HD [12], the membrane containing $0.5 \%$ zeolite was chosen for further studies.

The hydrophilic properties of membranes can be determined by measuring their contact angle after dropping $\sim 10 \mu \mathrm{l}$ of water onto the membranes. The results can be seen in Fig. 4.

Fig. 4 shows that the water curves decreased with increasing time, indicating membrane hydrophilicity. The addition of zeolite into the PES membrane was predicted to increase hydrophilicity by contributing hydroxyl species to the membrane surface. The improvement of the hydrophilic properties of a membrane is key to its application in $\mathrm{HD}$ and overcoming the fouling problem commonly observed in hydrophobic membranes. 
a)

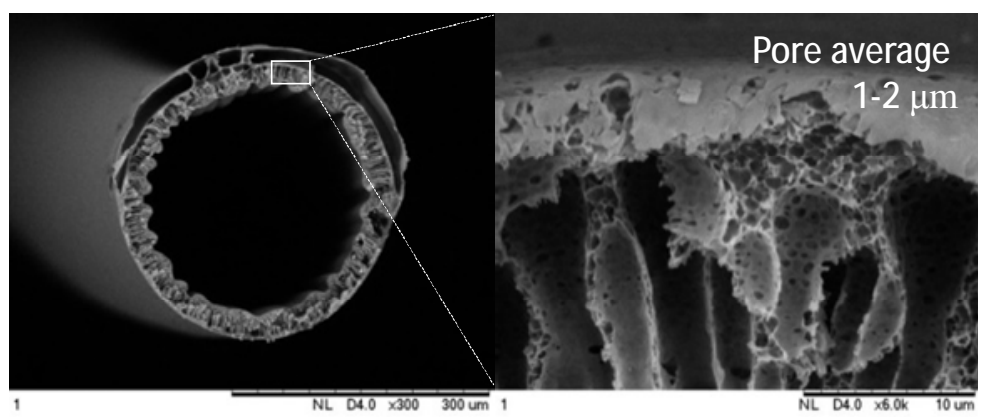

b)

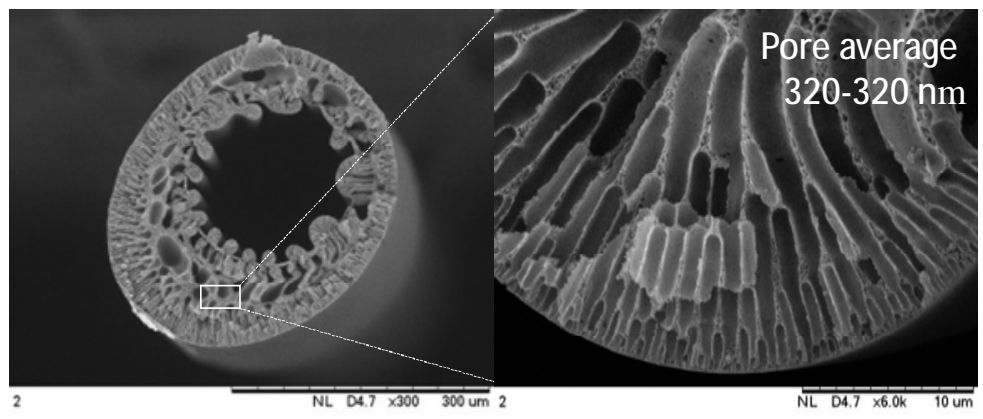

Fig. 5. SEM images of PES (a) and PES-zeolite (b)

SEM investigations were performed to study how the morphological structure of membranes was affected by the addition of zeolite. The surface structure and crosssection figures, seen in Fig. 5, reveal that the forms of the pores in bare PES and zeolite-modified PES are different. The pores in bare PES were not well-ordered, and the addition of zeolite made them well-ordered and asymmetric, thereby improving the ultrafiltration of uremic toxin compounds.

The pore sizes of the PES membranes were observed to be $1-2 \mu \mathrm{m}$ based on the SEM results, and became smaller with the addition of zeolites $(\sim 320-370 \mathrm{~nm})$. According to Meyer [13], pore sizes for the ultrafiltration membrane should be in the range of $0.1-0.001 \mu \mathrm{m}$.

\subsection{Performance of the PES-Zeolite Hollow Fibre Membrane}

The flux value of membranes, which is indicative of the ultrafiltration flow rate, was $51.02 \mathrm{l} / \mathrm{m}^{2} \cdot \mathrm{h}$; the rejection value of the hollow fibre membrane was $8.01 \%$, suggesting a decrease in creatinine concentration by $91.99 \%$ after passing through the hollow-fibre membranes. The flux and creatinine rejection data reveal that the membranes are suitable for HD, since normal PES membranes have a creatinine rejection rate of $55 \%$. These interesting results reveal that a potent blend of PES and zeolite can be applied for HD.

\section{Conclusions}

Fabrication of hollow fibre membrane was successfully done using the spinneret as a casting instrument. The optimum concentration of PES:zeolite:DMF $(\mathrm{w} / \mathrm{w})$ was 17:0.5:82.5. The resulted PES-zeolites hollow fibre membranes show maximum great mechanical properties for its stress, strain and Young's modulus, which were found to be $25 \mathrm{kN} / \mathrm{m}^{2}, 0.01 \mathrm{~mm}, 25 \cdot 10^{6} \mathrm{~N} / \mathrm{m}^{2}$, respectively. The flux and rejection values were found to be $51.02 \mathrm{l} / \mathrm{m}^{2} \cdot \mathrm{h}$ and $8.01 \%$, respectively.

\section{Acknowledgments}

Authors would like to thank the Ministry of Research, Technology and Higher Education for research funding program and Universitas Airlangga for facilities support.

\section{References}

[1] Indonesian Renal Registry. $7^{\text {th }}$ Report of Indonesian Renal Registry. 2014.

http://www.indonesianrenalregistry.org/data/INDONESIAN\%20RE NAL\%20REGISTRY\%202014.pdf

[2] Levey A., Bosch J., Lewis J. et al.: Ann. Intern. Med., 1999, 130, 461. https://doi.org/10.7326/0003-4819-130-6-19990316000002

[3] Prestisya I.: Doct. Thesis, Universitas Airlangga, Surabaya 2016. [4] Ghobarkar H., Schäf O., Guth U.: Progr. Solid State Chem., 1999, 27, 29. https://doi.org/10.1016/S0079-6786(00)00002-9 [5] Namekawa K., Schreiber M., Aoyagi T., Ebara M.: Biomater. Sci., 2014, 2, 674. https://doi.org/10.1039/c3bm60263j 
[6] Lu L., Samarasekera C., Yeow J.: J. Appl. Polym. Sci., 2015, 132. https://doi.org/10.1002/app.42418

[7] Itoh S., Susuki C., Tsuji T.: J. Biomed. Mater. Res.-A, 2006, 77, 294. https://doi.org/10.1002/jbm.a.30608

[8] Sawada I., Fachrul R., Ito T. et al.: J. Membrane Sci., 2012, 387, 1. https://doi.org/10.1016/j.memsci.2011.06.020

[9] Arahman N., Maruyama T., Sotani T., Matsuyama H.: J. Appl. Polym. Sci., 2009, 111, 1653. https://doi.org/10.1002/app.29149

[10] Duxson P., Lukey G., van Deventer J.: J. Non-Cryst. Solids, 2007, 353, 2186. https://doi.org/10.1016/j.jnoncrysol.2007.02.050 [11] Okada K., Shimizu Y.-I., Kameshima Y., Nakajima A.: J. Porous Mat., 2005, 12, 281. https://doi.org/10.1007/s10934-005-3126-x

[12] Han W., Liu C., Bai R.: J. Membrane Sci., 2007, 302, 150. https://doi.org/10.1016/j.memsci.2007.06.039

[13] Sawada I., Fachrul R., Ito T. et al.: J. Membrame Sci, 2012, 387-388, 1. https://doi.org/10.1016/j.memsci.2011.06.020

Received: July 13, 2017 / Revised: November 06, 2017 / Accepted: January 20, 2018

\section{НОВІ, МОДИФІКОВАНІ ЦЕОЛІТОМ ПОЛІЕТЕРСУЛЬФОНОВІ МЕМБРАНИ З ПОРОЖНИСТИХ ВОЛОКОН ДЛЯ ГЕМОДІАЛІЗУ КРЕАТИНІНУ}

Анотація. Проведено модифікацію поліетерсульфонових мембран (ПЕС) иеолітом для підвищення їх здатності притягувати креатинін. Модифікацію проводили за різних конщентрацій та тривалості змішування. Визначенні механічні властивості ПЕС, отриманих за оптимальної концентрації. Визначені значення напруги при розтягненні, деформачії розтягнення та модуля Юнга, а також швидкості мембранного потоку й коефіиієнту затримки мембран.

Ключові слова: чеоліт, порожнисті волокна, креатинін, гемодіаліз. 